\title{
LIVED -IN EXPERIENCES OF PATIENTS WHO HAVE UNDERGONE KIDNEY TRANSPLANTATION
}

${ }^{*}$ Shalimol.U.S ${ }^{1},{ }^{* *}$ Karthik V Kumar , ${ }^{* * * *}$ Karthika Krishnan \& *****Linta Sara John

\begin{abstract}
Objectives: Elicit the lived in experience of patients who have undergone kidney transplantation2) Extrapolate the lived in experience of patients who have undergone kidney transplantation. Method Nonexperimental, descriptive study design with Qualitative approach Result The majority (60\%) of the participants were males and $60 \%$ of them were in the age group of 26-35 years. A vast majority (50\%) of participants of the study belonged to middle socio economic class with a monthly family income as Rs 5000-10,000. Majority (60\%) of the donors were family members. The following themes and subthemes were identified from the verbatim. In physical dimension, the identified theme were Gastric problems, headache, hypertension, weight reduction, edema, fatigue, glycaemia index ,UTI, tremor. Conclusion: The study findings reveal that we should give equal importance to all the dimensions which is of paramount importance to meet quality nursing care
\end{abstract}

Keywords: Lived-in experiences, kidney transplantation

\section{INTRODUCTION}

Human affliction is as old as human life with March of civilization as they only multiply in number and complexity. Over the last decades, studies have been enormously successful in identifying the risk factors for the major diseases. However, most of the researches have focused on the risk factors that are relatively proximal for causing the disease.

\section{Objectives of the study:}

1) Elicit the lived in experience of patients who have undergone kidney transplantation

2) Extrapolate the lived in experience of patients who have undergone kidney transplantation

\section{METHODOLOGY:}

Non-experimental, descriptive study design with Qualitative approach was adopted for the study. The study was conducted in nephrology and urology Out Patient Department (OPD) with 10 samples .The Sample was collected using convenience sampling method. It consisted of patients who underwent renal transplant within period of 6 months to ten years. The Data collection tool consisted of Socio demographic data and Unstructured Interview schedule .A in depth interview was done till the data saturation point. The data thematically was analyzed using modified Colaizzi's analysis framework 
Results and Discussion

Frequency and percentage distribution of socio-demographic variables among patients undergone renal transplantation.

$\mathbf{N}=\mathbf{1 0}$

\begin{tabular}{|c|c|c|c|}
\hline Sl.No & $\begin{array}{l}\text { Demographic } \\
\text { Variables }\end{array}$ & Frequency & Percentage(\%) \\
\hline 1. & $\begin{array}{l}\text { Age in years } \\
20-25 \\
25-30 \\
30-35 \\
>35\end{array}$ & $\begin{array}{l}2 \\
6 \\
2 \\
0\end{array}$ & $\begin{array}{c}20 \\
60 \\
20 \\
0\end{array}$ \\
\hline 2. & $\begin{array}{l}\text { Gender } \\
\text { Male } \\
\text { Female }\end{array}$ & $\begin{array}{l}6 \\
4\end{array}$ & $\begin{array}{l}60 \\
40\end{array}$ \\
\hline 3. & $\begin{array}{l}\text { Marital status } \\
\text { Married } \\
\text { Unmarried }\end{array}$ & $\begin{array}{l}7 \\
3\end{array}$ & $\begin{array}{l}70 \\
30\end{array}$ \\
\hline 4. & 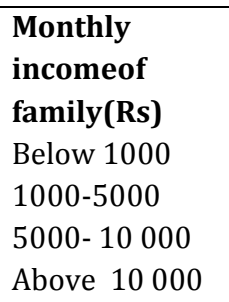 & $\begin{array}{l}5 \\
1 \\
4 \\
0\end{array}$ & $\begin{array}{c}50 \\
10 \\
40 \\
0\end{array}$ \\
\hline 5. & $\begin{array}{l}\text { Religion } \\
\text { Christian } \\
\text { Muslim } \\
\text { Hindu } \\
\text { Other }\end{array}$ & $\begin{array}{l}1 \\
0 \\
9 \\
0\end{array}$ & $\begin{array}{c}10 \\
0 \\
90 \\
0\end{array}$ \\
\hline 6. & 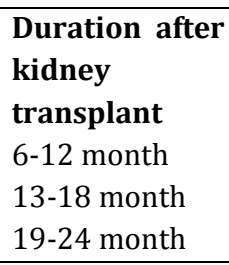 & $\begin{array}{l}6 \\
3 \\
1\end{array}$ & $\begin{array}{l}60 \\
30 \\
10\end{array}$ \\
\hline 7. & $\begin{array}{l}\text { Organ donors } \\
\text { Mother } \\
\text { Father } \\
\text { Brother } \\
\text { Wife }\end{array}$ & $\begin{array}{l}6 \\
1 \\
1 \\
2\end{array}$ & $\begin{array}{l}60 \\
10 \\
10 \\
20\end{array}$ \\
\hline
\end{tabular}

RESULTS

Socio-demographic variables among patients undergone renal transplantation

The majority (60\%) of the participants were males and $60 \%$ of them were in the males and $60 \%$ of them were in the the

age group of 26-35 years. A vast majority (50\%) of participants of the study was belonging to middle socio economic class with a monthly family income as Rs 500010 ,Majority (60\%) of the donors were family members . The following themes and subthemes were identified from the verbatim.

- In physical dimension, the identified theme were Gastric problems , headache, hypertension, weight reduction, edema ,fatigue, glycaemia index ,UTI, tremor. Among the physical dimension a vast majority has gastric problem than rest of themes like weight variation, headache, fatigue and generalized weakness.

- In psychological dimension the identified themes were depression, fear , stress, glad, and certitude ,anxious. majority of them had fear as a chief problem. In social dimension the identified themes were related to participation in social \& family gatherings and support system ,majority of sample gave importance to support system.

- In Spiritual dimension included two major themes like theism and atheism, majority of the people had theism.

- In Economical dimension major themes like financial dependence, financial independence among that majority of the sample were financial dependent. Investigator felt Most inspiring verbatim as 10 years of life after kidney transplant the participant said “I don't have much problems after kidney transplantation ", ,...pause a small smile in her face ,looks happy , “ only after 4-5years i had little fatigue after coming home from work ,it gets better after taking a nap that is only difficulty i had till date". 
Investigator felt most touching verbatim as"I can adopt to all therapeutic changes imposed on me , very easily ..........but i feel sad because the donor is my father", with tears rolling down her eyes ......A qualitative study conducted by Alison tong Rachael morton (oct 2009) on adolescent experiences following organ transplantation : A systematic review of qualitative studies, .with the objective to describe the experiences of adolescents who underwent organ transplantation. The result showed that eighteen articles reporting the experience of 313 adolescent organ transplant recipients were included. Five major theme were identified .(1) redefining and identifying (seeking normality , anxiety and disappointment, adopting a positive attitude, deserving independents).(2) family functioning ( parental over protection, sibling support ).(3) social adjustment ( support networks, peer rejection, maintaining school work, participation in physical activities).(4) managing medical demand ( assuming responsibility, dependence on caregivers , disruption of life style vigilant adherence, pain and discomfort); and (5) attitude towards the donors ( obligation of gratitude, strengthened relationship, concerns about risk of donors)

\section{Conclusion}

The study findings reveal that we should give equal importance to all the dimensions which is of paramount importance to meet quality nursing care.

\section{REFERENCES}

1.National institute of diabetes and digestive and kidney disease. 2014 may ; Available from: URL:http://www.niddk.nih.gov/healthinformation/health-topics/anatomy/kidneyhowthey-work/page/.aspx

2.Kidney failure. Available from: URL:http://www.medicnenet.com/kidneyfailure/ st-louisomo-city.htm

3.May transplant the human heart. 1908 January 2; Available from: URL:http://en.wikipedia.org/wiki/kidneytranspl antation

4.Unni VN. Amrita faculty as key opinion leader for kidney transplantation. [online] 2010 Aug 12; Available from: URL:http://www.amrita.edu./news/amritafaculty-key-opinion-leader 5.Bruce G and Jophelan. Journal of health and social behaviour. [online] 1995; 80-94. Available from: URL:http://www.jstor.org/stable/2626958 6.Sandeep s. Kidney transplantation experience. [online] 2013 july-december; vol 9:1-44. Available from:URL:http://medind.nic.in./aff/13/i2/aaft13i 2p24.pdf 